\title{
The determinants of capital structure for Japanese multinational and domestic corporations
}

\author{
Shumi Akhtar ${ }^{\mathrm{a}}$, Barry Oliver ${ }^{\mathrm{b}, *}$ \\ ${ }^{\mathrm{a}, \mathrm{b}}$ School of Finance and Applied Statistics, Faculty of Economics and Commerce, \\ Australian National University, Canberra, 0200, Australia
}

\begin{abstract}
Theoretically, it is often argued that the international diversification of earnings should enable multinational corporations to sustain higher levels of debt than domestic corporations. Studies using US multinationals often report lower leverage for multinationals relative to domestic corporations, while studies on samples of French and Canadian multinationals find the theoretical relation. This paper extends the research to Japanese multinationals. We find that being a multinational corporation is a significant variable in explaining capital structure for a sample of Japanese firms.

We also find that Japanese multinationals have significantly lower leverage than domestic firms. Using a pooled cross-sectional time series regression model with dichotomous interaction variables, the difference in leverage between multinational and domestic corporations is explained by firm age, business risk, free cash flow, growth, nondebt tax shields and political risks. Agency costs, bankruptcy risks, collateral value of assets, foreign exchange risks, profitability and size are not significant in explaining differences in capital structure between multinational and domestic corporations.
\end{abstract}

JEL classification: G15, G32

Keywords: Capital structure, leverage, multinational corporation

* Corresponding author. Tel.: +61 26125 0729; fax: +61 261250729.

Email address: Barry.Oliver@anu.edu.au. (B. Oliver)

Acknowledgements: Special thanks to Tom Smith and participants at the 2005 AFAANZ conference for comments on earlier drafts. 


\section{Introduction}

Corporate capital structure remains a controversial issue in modern corporate finance. Since the seminal work by Modigliani and Miller (1958), a plethora of research has been undertaken in attempting to identify the determinants of capital structure. Considerably less research has been undertaken in identifying if different types of corporations vary in their capital structure and their capital structure determinants. This is particularly the case for multinational corporations (MNCs) versus domestic corporations (DCs).

Theoretically, it is often argued that the international diversification of earnings should enable MNCs to sustain a higher level of debt than DCs, without increasing their default risk. Fatemi (1988), Lee and Kwok (1988), Burgman (1996), Chen et al. (1997), Homaifer, Zietz and Benkato (1998), Chkir and Cosset (2001) and Doukas and Pantzalis (2003) investigated capital structures between US based MNCs and DCs and all reported US MNCs as having less leverage than US DCs. This suggests that the effect of higher agency costs of debt for MNCs, as a result of capital and labor market imperfections, complexity of international operations and higher proportion of intangible assets, exceeds the possible benefits of international diversification and leads to lower debt ratios for MNCs (Chkir and Cosset, 2001). However, Singh and Nejadmalayeri (2004) find that international diversification is positively associated with higher leverage for a sample of French corporations and Mittoo and Zhang (2005) find Canadian MNCs to have higher leverage relative to Canadian DCs.

The inconsistency in evidence between US, French and Canadian studies warrants further investigation from other countries. We are therefore motivated to look for evidence in Japan. Japan is of interest for several reasons. First, existing studies rely primarily on the US evidence. The robustness of the US findings needs to be examined against evidence from other major industrialized countries such as Japan. Second, Japanese MNCs control substantial amounts of wealth and Japanese multinational corporations represent some of the 
largest corporations worldwide. Understanding the determinants of capital structure for both multinational and domestic corporations is important given the amount of wealth involved. Third, Japan has a unique corporate system with control mechanisms different from the US (He and $\mathrm{Ng}, 1998$ ). How this different system impacts on the determinants of capital structure between MNC and DCs will add insight into the debate on capital structure. Finally, to the best of our knowledge, no study has yet conducted a comprehensive analysis of the capital structure determinants of Japanese MNCs. Thus, Japan makes an interesting and attractive candidate for our study.

Therefore, we aim to identify the determinants of capital structure for a sample of Japanese corporations, to identify if being a Japanese multinational corporation is a determinant of capital structure and if the capital structure is different for multinational and domestic corporations, what explains the difference.

The analyses first considers the significance of standard determinants of capital structure over a 10 year period to 2003 for a sample of Japanese domestic and multinational corporations. Determinants of capital structure that are considered include age, agency costs, bankruptcy risks, business risks, collateral value of assets, free cash flows, foreign exchange risks, growth opportunities, non-debt tax shields, political risks, profitability and size. A dichotomous variable for multinationality is introduced to ascertain if being a multinational corporation is a determinant of capital structure. Then interactive dichotomous variables are introduced to ascertain the relative importance of being a multinational corporation for the determinants of capital structure.

On a univariate basis Japanese multinational corporations have significantly less leverage than Japanese domestic corporations. Also, they are significantly older, larger, and have significantly higher agency costs, business risks, free cash flows, foreign exchange risks, growth, non-debt tax shields, political risks and profitability, and they have 
significantly lower bankruptcy risks and collateral assets than Japanese domestic corporations.

The multivariate empirical findings show that being a multinational is a significant determinant of capital structure and that the determinants of capital structure are different for multinational and domestic corporations. Agency costs, business risks, collateral value of assets, profitability and size are significant determinants of capital structure for both multinational and domestic corporations. Firm age and free cash flows are significant determinants of capital structure for domestic corporations but not multinational corporations, whereas bankruptcy risks, growth and non-debt tax shields are significant for multinationals but not domestic corporations. Foreign exchange risk and political risk is not significant for either domestic or multinational corporations, although foreign exchange risk is significant in the sample overall. In relation to explanations for the observed difference in capital structure between domestic and multinational corporations we find firm age, business risks, free cash flows, growth, non-debt tax shields and political risks are significant.

The paper is divided into four sections. The next section reviews the relevant literature and defines the variables. The second provides discussion of the method and data respectively. Section three discusses the results and section four summarizes the key findings and concludes the paper.

\section{Capital structure determinants and variable definitions}

Modigliani and Miller (1958) are widely regarded as the pioneers in modeling the relevance of capital structure to firm value. Since then the debate has progressed from theoretical modeling to practical reality. It is recognized that by relaxing the assumptions of Modigliani and Miller (1958) capital structure is relevant to firm value. The variables that are generally regarded as determinants of capital structure include age, agency costs, bankruptcy risks, business risks, collateral value of assets, foreign exchange risks, free cash 
flows, growth, non-debt tax shields, political risks, profitability, and size. Generally, these variables relate to value and risks of the firm as faced by bondholders, equityholders and managers.

Apart from identifying the determinants of capital structure an important issue is defining what is meant by capital structure or leverage. Rajan and Zingales (1995) provide an overview of the different definitions of leverage. In relation to research on the capital structure of multinational corporations two main definitions of leverage have been applied. Doukas and Pantzalis (2003) and Mittoo and Zhang (2005) amongst others define leverage as long-term debt scaled by total debt plus market value of equity. Lee and Kwok (1988), Burgman (1996), Chen et al. (1997) and Chkir and Cosset (2001) amongst others define leverage as long-term debt scaled by long-term debt plus market value of equity. To provide a benchmark for comparability we use the later definition in our analysis and define leverage for firm $i$ at time $t$, as:

$$
\operatorname{LEVERAGE}_{i, t}=\frac{\text { Long term debt }_{i, t}}{\left(\text { Long term debt } t_{i, t}+\text { Market value of equity }_{i, t}\right)} \cdot 1
$$

\subsection{Age}

Petersen and Rajan (1994) show that leverage decreases with age of the firm. Although they cite agency issues as a potential explanation, age of the firm may also proxy for lower information asymmetries. As firms grow older more information regarding their future viability becomes available. Lower information asymmetries imply higher leverage. Bondholders would be more likely to lend to firms they know more about than lending to firms they know less about. Therefore, given this conflict we do not hypothesize what effect age has on leverage. However, we expect MNCs to be older than DCs since firms are

\footnotetext{
${ }^{1}$ Correlation analysis for our sample indicates over $90 \%$ correlation between the two measures.
} 
generally likely to begin as domestic corporations and expand over time to become multinationals.

The variable for firm age is measured following Michaelas, Chittenden and Poutziouris (1999) amongst others:

$A G E_{i, t}=\ln$ (age of firm $i$, in years from date of incorporation).

\subsection{Agency costs}

Higher agency costs are expected to result in lower debt levels (Jensen, 1986; Doukas and Pantzalis, 2003). Significant agency costs arise from the conflict of interest between stockholders and bondholders. The consistent message of agency models is that these conflicts create incentives for stockholders to take actions that benefit themselves at the expense of bondholders. Myers (1977) argues that agency problems are especially serious for assets that give the firm the option to undertake growth opportunities in the future. The greater the firm's investment in such assets the less it would be debt financed. MNCs agency costs are expected to be higher relative to DCs (Burgman, 1996). Therefore, we expect that MNCs leverage would be lower than DC's after controlling for all other effects. A proxy for agency costs is expenditure on research and development (Myers, 1977). Therefore, following Myers (1977) the variable used to proxy for agency costs is:

$$
A G N C Y_{i, t}=\frac{\text { Research } \text { and Development }_{i, t}}{\text { Total Sales }_{i, t}} .^{2}
$$

\subsection{Bankruptcy risks}

Bankruptcy risk has two components:

1. Probability of Bankruptcy.

\footnotetext{
${ }^{2}$ Included in this variable is often advertising expense however this was not available for our sample of firms.
} 
2. Costs of Bankruptcy (loss of customers, loss of reputation, legal costs etc).

Higher levels of debt will increase the probability of bankruptcy and increase bankruptcy costs. Therefore, we expect a positive relation between leverage and bankruptcy risks. Traditionally, many textbooks have argued theoretically that MNCs should be in a better position than their domestic counterparts to support higher debt because their cash flows are diversified internationally giving them lower risk of default (Eiteman, Stonehill and Moffett, 2001). However, some empirical studies have come to the opposite conclusion (Lee and Kwok, 1998; Burgman, 1996; Chen et al. 1997 amongst others).

If we proxy bankruptcy risks via a bankruptcy prediction model such as the Altman Z-score (Altman, 2000) we expect a negative relation between leverage and the Z-score. ${ }^{3}$ Bankruptcy risks for each firm are proxied with Altman's Z-score (Altman, 2000) ${ }^{4}$ :

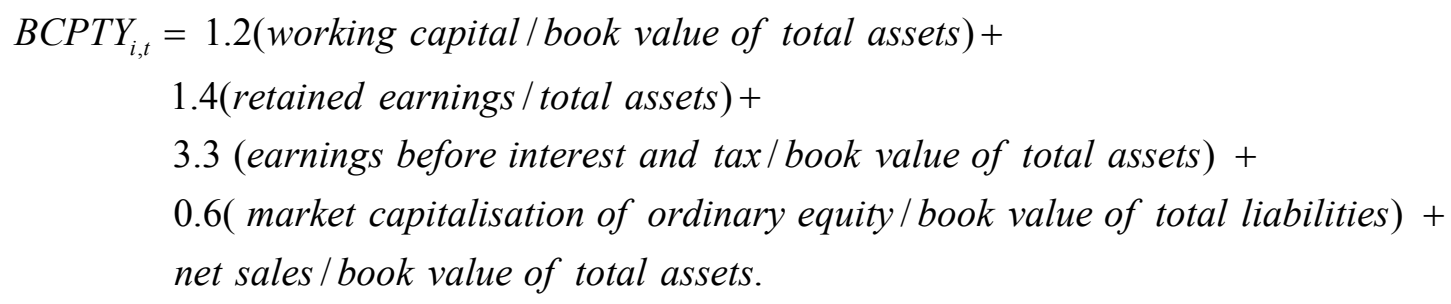

\subsection{Business risks}

Business risk refers to the risk associated with the future operations of the business. This is the risk that is inherent in the expected net operating income stream generated by the assets of the firm (Bishop, Faff, Oliver and Twite, 2004). A proxy for business risk is the equity beta adjusted for leverage or de-geared. Generally, it is expected that there is an inverse relation between leverage and business risk potentially due to the associated increase in bankruptcy risks (Burgman, 1996). In relation to MNCs, it is frequently argued that, due to their ability to diversify across less than perfectly correlated markets, business risks for MNCs should be less than DCs. MNCs should therefore be able to support relatively more

\footnotetext{
${ }^{3}$ We expect a negative relation because the higher the Z-score the lower the probability of bankruptcy.

${ }^{4}$ To minimise spurious correlation between our measure of leverage and Altmans's Z-score the Z-score is lagged one period.
} 
leverage. However, this has not always been supported empirically. For example, Reeb, Kwok and Baek (1998) report that US-based MNCs have higher systematic risk (after adjusting for leverage) than US domestic corporations.

We proxy business risk as the de-geared equity beta for each firm:

$$
\text { BUSRISK }_{i, t}=\text { De-geared equity beta }=\frac{\beta_{L}}{\left(1+\frac{D_{i, t}\left(1-t_{c}\right)}{E_{i, t}}\right)}
$$

where

$\beta_{L}=$ OLS regression on previous 52 weeks of returns with the market: $R_{i, w}=\alpha+\beta_{L}\left(R_{m, w}\right)+\varepsilon_{i, w}$ and $R_{i, w}=\ln \left(P_{i, w} / P_{i, w-1}\right)$. Where $P_{i, w}$ is the stock price at week $w$. The market index $\left(R_{m, w}\right)$ used was the Nikkei all stocks total index, and

$D_{i, t} \quad=$ Book value of total debt at end of year $t$;

$E_{i, t} \quad=$ Market capitalization of ordinary equity at end of year $t$; and

$t_{c} \quad=$ Corporate tax rate

\subsection{Collateral value of assets}

The collateral value of assets, or tangibility of assets, held by a firm has found to be a determinant of leverage (Rajan and Zingalis, 1995). Firms with higher tangible assets are expected to have higher leverage. Tangible assets are likely to have an impact on the borrowing decisions of a firm because they are less subject to informational asymmetries and usually they have a greater value than intangible assets in case of bankruptcy. Additionally, the moral hazard risks are reduced when the firm offers tangible assets as collateral, because this constitutes a positive signal to the debt holders. In relation to MNCs and DCs, it is uncertain whether the level of tangible assets is higher or lower for MNCs relative to DCs.

Following Friend and Lang (1988) we define the collateral value of assets for each firm as:

$$
C V A_{i, t}=\frac{\text { Book value of tangible assets }}{\text { Book value of total assets }}
$$




\subsection{Free cash flows}

Easterbrook (1984) and Jensen (1986) argue that excess free cash flow is cash flow in excess of that required to fund all projects that have positive NPV. Firms with excess free cash flow face conflicts of interest between stockholders and managers. The problem is how to motivate managers to distribute excess funds rather than investing them below the costs of capital or on organizational inefficiencies, such as management perks. Leverage is an effective means for addressing the free cash flow problem, because contractual payments of interest and principal must be made. Bondholders can take the firm to bankruptcy if managers do not maintain loan repayments. Accordingly, debt reduces the agency cost of free cash flows by reducing the cash flow available for spending at the discretion of managers (Stulz, 1990 and Harris and Raviv, 1991). Therefore, firms with higher free cash flow are expected to have lower leverage, an inverse relation. In relation to MNCs and DCs, it is uncertain whether the level of free cash flow is higher or lower for MNCs relative to DCs.

We define free cash flow as per Lehn and Poulsen (1989) standardized by the book value of total asset as:

$$
F C F_{i, t}=\frac{E B I T_{i, t}+D E P_{i, t}+A M O_{i, t}-T A X_{i, t}-D I V_{i, t}-I N T_{i, t}}{\text { Book value of total assets }}
$$

where:

$E B I T_{i, t}=$ earnings before interest and tax and abnormal items;

$D E P_{i, t}=$ depreciation expense;

$A M O_{i, t}=$ amortization;

$T A X_{i, t}=$ total tax paid;

$D I V_{i, t}=$ total dividends paid on ordinary and preference shares; and

$I N T_{i, t}=$ net interest expense; 


\subsection{Foreign exchange risks}

The more sensitive a firm's cash flows and earnings are to foreign exchange rates, the lower the expected level of debt. Burgman (1996) analyzed the relation between foreign exchange risk and corporate financing decisions and reported that foreign exchange risk significantly affects financing decisions. Further, exchange rate movements affects both the cash flows of a firm's operations and discount rates employed to value the cash flows (Bartov, Bodnar and Kaul, 1996). ${ }^{5}$ In relation to MNCs, we expect MNCs to have a higher exposure to foreign exchange risk than DCs. This implies that MNCs would have relatively lower leverage, after controlling for all other variables. However, foreign exchange risk is a risk commonly hedged by firms. Although MNCs may have greater exposure to foreign exchange risk, the risk may be hedged. Hedging is also available to DCs. Therefore, relative to DCs we cannot hypothesize what influence foreign exchange risk will have on capital structure of MNCs relative to DCs.

Foreign exchange risk exposure of each firm is defined as per Wright, Madura and Wiant (2002):

$$
F X_{i, t}=\frac{{\text { Total foreign } \text { sales }_{i, t}}_{\text {Total sales }}}{i, t}
$$

\subsection{Growth}

The expected relation between leverage and growth opportunities is not clear. The contracting hypothesis suggests that firms with higher growth are expected to have lower leverage. This is based on the underinvestment and asset substitution problems that debt is supported by assets-in-place rather than growth opportunities (Myers and Majluf, 1984; Titman and Wessels, 1988 and Gul, 1999). ${ }^{6}$ On the other hand, the signaling

\footnotetext{
${ }^{5}$ Bartov, Bodnar and Kaul (1996) shows that there is an increase in the variability of equity returns following the period of increased exchange-rate variability. The results suggest that the increase in exchange-rate fluctuations is an indication of an increase in the riskiness of cash flows.

${ }^{6}$ The underinvestment problem refers to the tendency of managers to reject positive NPV projects in which the value increase goes to bondholders rather than equityholders. This suggests that firms will issue debt when they have assets-in-place rather than when they have growth opportunities. Therefore, firms with higher
} 
hypothesis is based on the impact of information asymmetries on debt policies. For example, firms with higher growth opportunities face greater information disparities and therefore are expected to have higher debt levels to signal higher quality (Gul, 1999). This follows the default probability theory of Merton (1974) which also implies a positive relation between growth and leverage (Nishioka and Baba, 2004). Given this conflict we do not hypothesize the relation between leverage and growth. Similarly, we do not hypothesize whether growth is higher or lower for MNCs relative to DCs and the impact this has on MNCs capital structure.

Growth is defined by following Wald (1999), based on Myers (1977) underinvestment arguments of growth opportunity related agency costs:

$$
G R O W_{i, t}=\text { Average } \% \text { change in book value of total assets over past } 4 \text { years } .
$$

\subsection{Non-debt tax shields}

Taxation and its relation to capital structure are explicitly linked to the applicable tax regime. Under the Japanese classical tax system the tax deductibility of interest is expected to induce a preference for debt. De Angelo and Masulis (1980) formalized a framework whereby tax deductions that are not associated with debt act as substitutes for interest deductions. These non-debt tax shields compete with interest as a tax deduction. Firms with higher non-debt tax shields are expected to have lower leverage, as the tax benefits of leverage are relatively less valuable. MNCs should be better equipped than DCs to exploit taxation regulation across different countries for the purpose of reducing their tax liabilities. However, we make no hypothesis as to the relative difference in non-debt tax shields

growth opportunities are expected to have less leverage. The asset substitution problem refers to the tendency of managers to switch from low risk assets to high risk assets to transfer wealth from bondholders to equityholders. This is more likely to happen in firms with higher growth opportunities (less assets-in-place) as it is easier to switch assets if they are in the form of growth opportunities. Therefore, firms with higher growth opportunities are expected to have less leverage. 
between MNCs and DCs. If MNCs have higher levels of non-debt tax shields we expect them to have lower leverage, all other things constant.

Following Bradley, Jarrell and Kim (1984) and Titman and Wessels (1988) we define non-debt tax shield as:

$$
\text { NDTS }_{i, t}=\frac{\text { Total annual depreciation expense }}{i, t}
$$

\subsection{Political risks}

Political risk is the chance that political events will have an adverse effect on the operations of the firm. Political risks include expropriation of assets, trade controls, institutional ineffectiveness, threat of war, social unrest, disorderly transfers of power, political violence, international disputes, regime changes and regulatory restrictions (Jodice, 1985). Firms that face higher political risks are expected to have less leverage due to greater probability of misappropriation of assets. MNCs operating overseas subsidiaries are expected to have higher political risks than DCs. Therefore, given a negative relation between political risk and leverage we expect that MNCs would have less leverage relative to DCs after controlling for other variables.

Political risk of each firm is measured as follows. Let $C$ be the sample of companies and $R$ the set of different countries that companies in the sample operate from. Let $I_{c, r}$ be the revenue of company $c$ coming from a particular country, $r$. The sum of revenues for company $c$, from different countries is the sum of $I_{c, i} . \quad P_{c, r}$ is the proportion of revenue from a particular country relative to the total revenue of company $c$. Notationally, this is as follows:

$$
P_{c, r}=\frac{I_{c, r}}{\sum_{i \in R} I_{c, i}} .
$$

For each country in which a company operates a political risk rating is obtained from the PRS group Handbook of Country and Political Risk Analysis (Howell, 2005). This is 
denoted as lambda $\left(\lambda_{i}\right)$. The political risk rating is then multiplied by the proportion of revenue from that particular country relative to the total revenue of the company. This provides a measure of political risk faced by the firm. The maximum value of this political risk rating variable is 100 . This indicates the lowest level of political risk. A minimum value of zero indicates the riskiest political risk rating. To ease interpretation we subtract the rating $\left(\gamma_{c}\right)$ from 100 to end up with the most risk as 100 and the least risk as zero. In notation this is as follows:

$$
P O L R_{i, t}=100-\gamma_{c}=100-\sum_{i \in R} \lambda_{i} P_{c, i}=100-\frac{\sum_{i \in R} \lambda_{i} I_{c, i}}{\sum_{i \in R} I_{c, i}} .
$$

\subsection{Profitability}

Myers (1984) pecking order theory of capital structure shows that if a firm is profitable then it is more likely that financing would be from internal sources rather than external sources. More profitable firms are expected to hold less debt, since it is easier and more cost effective to finance internally. MNCs have better opportunities than DCs to earn more profit mainly due to having access to more than one source of earnings and better chances to have favorable business conditions in particular countries (Kogut, 1985 and Barlett and Ghoshal, 1989). Consequently, MNCs being more profitable than DCs are expected to have lower leverage than DCs after controlling for the other variables.

The variable chosen to measure profitability for each firm follows Doukas and Pantzalis (2003):

$P R O F_{i, t}=$ Average net income to total sales for past 4 years. 


\subsection{Size}

Firm size has been found to be a positive determinant of capital structure (Agrawal and Nagarajan, 1990). Firm size may be a proxy for numerous variables such as lower transaction costs in issuing debt, greater access to debt markets and lower information asymmetries. In relation to MNCs and DCs, it is expected that MNCs are larger than DCs. Therefore, we expect that MNC would carry higher debt levels relative to DCs, after controlling for all other variables.

The natural logarithm of total assets is commonly considered a proxy for the size of each firm:

$$
S I Z E_{i, t}=\operatorname{Ln}\left(\text { Book value of total } \text { assets }_{i, t}\right) \text {. }
$$

In summary, although many determinants of capital structure can be explained for firms generally, the different impact they may have on capital structure between MNCs and DCs is often unclear.

\section{Method and Data}

\subsection{Method}

A pooled cross-sectional time series regression model (Model 1) is used to analyze capital structure determinants:

$$
\begin{aligned}
\text { LEVERAGE }_{i, t} & =\alpha_{i}+\beta_{1} A G E_{i, t}+\beta_{2} A G N C Y_{i, t}+\beta_{3} \text { BCPTY }_{i, t}+\beta_{4} \text { BUSRISK }_{i, t} \\
& +\beta_{5} \text { CVA }_{i, t}+\beta_{6} \text { FCF }_{i, t}+\beta_{7} F X_{i, t}+\beta_{8} \text { GROW }_{i, t}+\beta_{9} \text { NDTS }_{i, t}+\beta_{10} \text { POLR }_{i, t} \\
& +\beta_{11} \text { PROF }_{i, t}+\beta_{12} \text { SIZE }_{i, t}+\varepsilon_{i, t}
\end{aligned}
$$

The variables are as previously defined.

Model 1 will be estimated using the full sample of both Japanese MNCs and DCs and then separately for MNCs and DCs. This will provide evidence of the significance of the determinants of capital structure for Japanese firms generally and then MNCs and DCs.

To assess the significance of multinationality in explaining capital structure, a dichotomous variable for multinationality will be augmented into Model 1 using the full 
sample and a Likelihood Ratio (LR) test will be conducted. The LR test enables us to determine whether multinationality makes a significant contribution to explaining variation in leverage.

Model 2 is relevant for identifying the significance of capital structure determinants for MNCs relative to DCs. It is a pooled cross-sectional time series regression model with a dichotomous variable and dichotomous interaction variables for multinationality:

$$
\begin{aligned}
& \text { LEVERAGE }_{i, t}=\alpha_{i}+\beta_{1} A G E_{i, t}+\beta_{2} A G N C Y_{i, t}+\beta_{3} B_{C P T Y}+\beta_{4} \text { BUSRISK }_{i, t}+\beta_{5} C V A_{i, t}+\beta_{6} F C F_{i, t} \\
& +\beta_{7} F X_{i, t}+\beta_{8} G R O W_{i, t}+\beta_{9} N D T S_{i, t}+\beta_{10} P O L R_{i, t}+\beta_{11} P R O F_{i, t}+\beta_{12} S_{I Z E_{i, t}} \\
& +\beta_{13} M U L T_{i}+\beta_{14}\left(M U L T_{i}^{*} A G E_{i, t}\right)+\beta_{15}\left(M U L T_{i}^{*} A G N C Y_{i, t}\right)+\beta_{16}\left(M U L T_{i}^{*} B C P T Y_{i, t}\right) \\
& +\beta_{17}\left(M_{U L T} * B U S R I S K\right)+\beta_{18}\left(M_{i} T_{i}^{*} C V A_{i, t}\right)+\beta_{19}\left(M_{U L T} * F C F_{i, t}\right) \\
& +\beta_{20}\left(M U L T_{i}^{*} F X_{i, t}\right)+\beta_{21}\left(M U L T_{i}^{*} G R O W_{i, t}\right)+\beta_{22}\left(M U L T_{i}^{*} N D T S_{i, t}\right) \\
& +\beta_{23}\left(M U L T_{i}^{*} P O L R_{i, t}\right)+\beta_{24}\left(M U L T_{i}^{*} P R O F_{i, t}\right)+\beta_{25}\left(M U L T_{i}^{*} \operatorname{SIZE}_{i, t}\right)+\varepsilon_{i, t}
\end{aligned}
$$

where

$M U L T_{i}=$ a dichotomous variable equal to unity if firm $i$, is a $\mathrm{MNC}$ and zero otherwise; and the other variables are as previously defined.

The purpose of the interaction dichotomous variables $\left(M U L T_{i}\right)$ is to allow the significance of the determinants of leverage for MNCs relative to DCs to be determined. In other words, if any of the coefficients $\beta_{14}$ through $\beta_{25}$ are significant then the associated variable is significantly explaining differences in capital structure between MNCs and DCs. ${ }^{7}$ An LR test will be conducted to ascertain the significance of augmenting the dichotomous variable into Model 2 as a separate independent variable. Appropriate adjustments for heteroscedasticity will be made using White (1980) heteroscedasticity-consistent standard errors and covariance.

\footnotetext{
${ }^{7}$ The magnitude each variable has on explaining leverage for MNCs is the sum of both coefficients. For example the relation size of MNC has on explaining leverage consists of summing $\beta_{12}$ and $\beta_{25}$.
} 


\subsection{Data}

Three hundred and sixty Japanese corporations that existed over the period 1994 to 2003 were initially randomly selected from the Osiris database. If a firm reported having at least one overseas subsidiary in 2003 and reported foreign sales in any year it was coded as a multinational corporation. ${ }^{8}$ Of the 360 firms, 209 were coded as multinational corporations and 147 were coded as domestic corporations.

\section{Results}

Table 1 contains descriptive statistics of the dependent and independent variables used in the regression models.

\section{[TABLE 1 HERE]}

Table 1 provides some surprising results. Characteristics of MNCs and DCs differ significantly on all variables. In relation to leverage, Japanese MNCs have significantly less leverage than Japanese DCs. In regards to the independent variables MNCs are on average approximately 11 years older than DCs. ${ }^{9}$ The proxy for agency costs are approximately twice as high for MNCs than DCs, indicating that MNCs invest significantly more in research and development than DCs. Altman Z-score (lagged one period), as a proxy for bankruptcy risks, is significantly higher for MNCs relative to DCs indicating that MNCs have a lower probability of bankruptcy. Business risk, as proxied by de-geared equity beta, is significantly higher for MNCs than DCs. Collateral value of assets is significantly higher for DCs than MNCs, indicating that Japanese domestic corporations have relatively higher levels of tangible assets than their MNC counterparts. MNCs have significantly higher levels

\footnotetext{
${ }^{8}$ Different studies have used different definitions of multinationality. Information on Osiris for the number of overseas subsidiaries was only available in 2003 . We do not consider this a significant problem as anecdotal evidence suggests that the number of overseas subsidiaries remains relatively constant over time. MNCs had foreign sales on average in five of the 10 years and DCs had foreign sales on average in one of the 10 years.

${ }^{9} \mathrm{e}^{4.14}=63$ years and $\mathrm{e}^{3.95}=52$ years.
} 
of free cash flows indicating greater potential conflicts of interest between stockholders and managers.

MNCs on average have approximately $20 \%$ of sales in foreign currency. This compares to only a little over $3 \%$ for domestic corporations. Although this may translate to potential foreign exchange risk, the foreign currency exposures may be hedged and the risks transferred.

MNCs have significantly higher growth opportunities than DCs and also significantly higher non-debt tax shields. Political risk faced by Japanese MNCs is significantly higher than those faced by DCs. MNCs are also significantly more profitable and significantly larger than DCs.

In summary, the results are generally similar to many US studies. Particularly important is our finding that Japanese MNCs have significantly less leverage than Japanese DCs. However, Japanese multinational corporations are very different from domestic corporations on all the twelve determinants of capital structure.

Table 2 provides regression results for Model 1. Significant F-statistics and adjusted $\mathrm{R}^{2}$ in excess of $50 \%$ across all three regressions suggests that the model fits well statistically.

\section{[TABLE 2 HERE]}

The results show that age is a significant variable in explaining leverage for the full sample of Japanese firms and for domestic firms. Firms that are older generally have higher leverage except if the firm is a multinational. Age is not a significant determinant of capital structure for multinationals even though MNCs are significantly older than DCs.

The proxy for agency costs is negative and significant across all three regressions indicating that firms with higher agency costs have lower leverage. This is as we expected.

The bankruptcy variable is significantly negative for the full sample indicating that the higher the bankruptcy measure, the lower the leverage. This is as expected as the higher 
the Altman Z-score the lower the probability of bankruptcy. This is similarly the case for MNCs. However, bankruptcy risk does not show up as a significant determinant of leverage for DCs. This is a somewhat surprising result and not as we expected.

Business risk is negative and significant across all three regressions indicating that firms with higher business risk (as proxied by the de-geared beta) have less leverage, this is as we expected.

Collateral value of assets is positive and significant across all three regressions. This indicates that firms with higher levels of tangible assets have higher leverage, again this is as we expected. The free cash flow variable is insignificant in the full sample and for MNCs but is significant for DCs. This is contrary to our expectations. However, it is negative across all regressions as we hypothesized.

The foreign exchange risk variable is negative and significant for the full sample. However, when the sample is divided into DCs and MNCs foreign exchange risk is not a significant determinant of leverage for either type of corporation.

The growth variable is negative and significant for only MNCs. Similarly, non-debt tax shields are only significant for MNCs. Political risk is not a significant explanatory variable of leverage in the sample of Japanese corporations or for MNCs and DCs separately.

More profitable firms have significantly less leverage regardless of whether they are MNCs or DCs. This supports the pecking-order theory of capital structure for both MNCs and DCs. Larger firms have a significantly higher leverage as hypothesized irrespective of whether they are MNCs or DCs.

Generally, the results of Model 1 on the full sample support many of the standard theoretical determinants of capital structure. When the sample is divided into MNCs and DCs significant differences in the determinants appear. Although the results of Model 1 show that the determinants of capital structure differ depending upon whether the firm is a 
domestic or multinational corporation, the results of Model 1 do not show what explains the difference in leverage between MNCs and DCs or even if being a multinational is a significant explanatory variable for capital structure.

To assess the impact of multinationality, the dichotomous variable for multinationality $\left(M U L T_{i}\right)$ was introduced into Model 1 . A LR test was performed to assess the significance of this variable. The results indicate that multinationality is a significant variable in capital structure determination $(\mathrm{LR}$ F-stat $=8.24$; prob $=0.004$; co-efficient $=-0.04$; $\mathrm{t}$-stat $=-2.75$; prob-value $=0.006$ ). The negative sign on the coefficient indicates that MNCs have significantly lower leverage than DCs, confirming the univariate results on leverage (see Table 1). To help explain the difference in leverage between MNCs and DCs and to assess the impact of individual economic determinants on multinational corporations Model 2 was estimated.

\section{[TABLE 3 HERE]}

The results of Model 2 are shown in Table 3. The adjusted R-squared is 53\% and the regression is highly significant $(\mathrm{F}-\mathrm{stat}=36.28$; prob-value $=0.00)$. The dichotomous variable for multinationality is insignificant. Furthermore, the LR test indicated insignificance for this variable in explaining variation in leverage (LR F-stat $=2.25$; prob=0.13). Therefore, the interacting dichotomous variables are adequately capturing differences in the economic determinants of capital structure for MNCs and DCs. ${ }^{10}$

The results of Model 2 show that age is a significant positive variable in explaining capital structure for DCs (confirming results of Model 1). Although age is not a significant determinant of leverage for MNCs (Model 1) it is significantly less important in explaining differences in leverage between DCs and MNCs. A reason for this result is that even though

\footnotetext{
${ }^{10}$ Running the regression without the dichotomous variable for multinationality did not change the significance of any of the remaining variables.
} 
MNCs are significantly older than DCs, once firms are in a mature phase of their life being older is less important in explaining capital structure.

The insignificant interaction variable on agency costs implies that agency costs do not explain differences in leverage between MNCs and DCs. This is contrary to our expectation that higher agency costs for MNCs relative to DCs would result in lower leverage for MNCs. However, as shown in Table 2 agency costs are a significant explanatory variable for both MNCs and DCs.

Although the bankruptcy variable is significant in the full sample and for MNCs (Table 2), when the impact of multinationality is isolated it becomes insignificant and bankruptcy does not significantly explain differences in leverage between MNCs and DCs.

The interaction variable for business risk is positive and significant. Although business risk is a significant determinant of capital structure for both MNCs and DCs (as shown in Table 2), the higher business risk faced by MNCs is significantly less important in explaining differences in the capital structure between MNCs and DCs.

The level of collateral assets is positive and significant in explaining capital structure for both MNCs and DCs (Table 2), it is not a significant variable in explaining differences in capital structure between the two types of organisations. Although MNCs have significantly lower levels of collateral assets than DCs, this does not help in any significant way to explain differences between MNCs and DCs capital structures.

MNCs have significantly higher free cash flow than DCs (Table 1), this higher free cash flow is not a significant determinant of MNCs capital structure (Table 2) but the higher free cash flow is significant in explaining differences in capital structure between MNCs and DCs (Table 3).

Although foreign exchange risk is significant in explaining capital structure for Japanese firms generally the significance of this variable diminishes when multinationality is 
isolated in the sample (Table 2). This insignificance remains the case in explaining differences in capital structure between MNCs and DCs (Table 3).

The growth variable is significant in explaining the capital structure for MNCs (Table 2) and the higher growth of MNCs (Table 1) is significant in explaining differences in leverage between MNCs and DCs (Table 3).

Non-debt tax shields are not significant in explaining capital structure for DCs but are significant in explaining capital structure for MNCs (Table 2). Non-debt tax shields are significant in explaining differences in capital structure between the two types of organizations (Table 3). MNCs may be better able to utilize non-debt tax shields than DCs, as we expected.

Although political risk is significantly higher for MNCs (Table 1) it is not a significant explanatory variable for capital structure (Table 2). However, difference in political risk faced by MNCs and DCs is a significant variable in explaining differences in capital structure between them. It is significantly less important in explaining leverage for MNCs relative to DCs.

The impact of profitability and size are not significant in explaining differences in capital structure for multinational corporations and domestic corporations in the sample of Japanese firms.

\section{Conclusion}

This paper documents the determinants of capital structure for a sample of 360 Japanese multinational and domestic corporations over a 10-year period to 2003. We report that Japanese multinational have significantly less leverage than Japanese domestic corporations. We also report that Japanese multinational corporations are significantly older, larger and have significantly higher agency costs, business risks, free cash flows, foreign exchange 
risks, growth, non-debt tax shields, political risks and profitability and significantly lower bankruptcy risks and collateral assets than Japanese domestic corporations.

Being a multinational corporation in Japan is significant in explaining capital structure for firms generally. In addition, the economic determinants of capital structure are not consistent for domestic and multinational corporations. We find that economic determinants of capital structure for Japanese domestic corporations include firm age, agency costs, business risks, collateral value of assets, free cash flow, profitability and size.

For multinational corporations the economic determinants of leverage are agency costs, bankruptcy risks, business risks, collateral value of assets, growth, non-debt tax shields, profitability and size. We find firm age, business risks, free cash flows, growth, non-debt tax shields, political risks and profitability are the significant variables that explain the difference in leverage between the sample of domestic and multinational corporations in Japan. 


\section{References}

Agrawal, A., and Nagarajan, N.J. 'Corporate capital structure, agency costs and ownership control: The case of all-equity firms', Journal of Finance, 45(4) (1990), 1325-31.

Altman, E. Predicting Financial Distress of Companies: Revisiting the Z score and Zeta Models, Working Paper, Stern School of Business, New York University, (2000).

Barlett, C.A. and Ghoshal, S. Managing across borders: The transnationals solution, Cambridge, MA, Harvard Business School Press, (1989).

Barton, S.L., Hill, N.C. and Sundaram, S. 'An empirical test of stakeholder theory predictions of capital structure', Financial Management 18(1) (1989), 36-44.

Bartov, E., Bodnar, G. and Kaul, A. 'Exchange rate variability and the riskiness of US multinational firms: Evidence from the breakdown of Bretton Woods', Journal of Financial Economics 42 (1996), 105-32.

Bishop, S., Faff, R., Oliver, B. and Twite, G. Corporate Finance, $5^{\text {th }}$ ed, Pearson Education, Australia (2004).

Bradley, M., Jarrell, G. and Kim, E.H. 'On the Existence of an Optimal Capital Structure: Theory and Evidence', Journal of Finance 39 (1984), 857-78.

Burgman, T.A. 'An empirical examination of multinational corporate capital structure', Journal of International Business Studies 27(3) (1996), 553-57.

Chen, C.J.P., Cheng, A., He, N. and Kim, J. 'An investigation of the relationship between international activities and capital structure', Journal of International Business Studies 23(3) (1997), 563-77.

Chittenden, F., Hall G. and Hutchinson, P. 'Small firm growth, access to capital markets and financial structure: Review of issues and an empirical investigation', Small Business Economics 8(1) (1996), 59-67.

Chkir, I.E. and Cosset, J-C. 'Diversification strategy and capital structure of multinational corporations', Journal of Multinational Financial Management 11 (2001), 17-37.

De Angelo, H. and Masulis R.W. 'Leverage and dividend irrelevancy under corporate and personal taxation', Journal of Finance 35(2) (1980), 453-64.

Doukas, J.A. and Pantzalis, C. 'Geographic diversification and agency costs of debt of multinational firms', Journal of Corporate Finance 9 (2003), 59-92.

Easterbrook, F. 'Two agency cost explanations of dividends', American Economic Review 74 (1984), 650-659.

Eiteman, D., Stonehill, A. and Moffett, M. Multinational Business Finance, $9^{\text {th }}$ edition, Addison-Wesley, USA (2001).

Fatemi, A. 'The effect of international diversification on corporate financing policy', Journal of Business Research 16 (1988), 17-30.

Friend, I. and Lang, L.H. 'An empirical test of the impact of managerial self-interest on corporate capital structure', Journal of Finance 43 (1988), 271-81.

Gul, F. 'Growth opportunities, capital structure and dividend policies in Japan', Journal of Corporate Finance 5 (1999), 141-168.

Harris, M. and Raviv, A. 'The theory of capital structure', Journal of Finance 49 (1991), 297-355.

$\mathrm{He}, \mathrm{J}$. and $\mathrm{Ng}$, L. 'The foreign exchange exposure of Japanese multinational corporations', Journal of Finance 53(2) (1988), 733-753.

Homaifer, G., Zietz, J. and Benkato, O. 'Determinants of capital structure in multinational and domestic corporations', Economia Internazionale 51(2) (1998), 189-210.

Howell, L. Handbook of Country and Political Risk Analysis, $3^{\text {rd }}$ Edition, (PRS Group), (2005).

Jensen, M.C. 'Agency costs of free cash flow, corporate finance and take-overs', American Economic Review 76 (1986), 323-39. 
Jodice, D. Political Risk Assessment: An Annotated Biography, Greenwood Press,Westport, (1985).

Kogut, B. The Multinational Corporations in 1980's, MIT Press, Cambridge, MA, (1985).

Lee, K. and Kwok C.Y. 'Multinational corporations vs. domestic corporations: International environmental factors and determinants of capital structure', Journal of International Business Studies 19 (1988), 195-217.

Lehn, K. and Poulsen, A. 'Free cash flow and stockholder gains in going private transactions', Journal of Finance 3 (1989), 771-87.

Merton, R.C. 1974, 'On the pricing of corporate debt: The risk structure of interest rates', Journal of Finance 29 (1974), 449-470.

Michaelas, N., Chittenden, F. and Poutziouris, F. 'Financial policy and capital structure choice in U.K. SMEs: Empirical evidence from company panel data', Small Business Economics 12 (1999), 113-30.

Mittoo, U. and Zhang, Z. 'The capital structure of multinational corporations: Canadian evidence', Working paper, I.H. Asper School of Business, University of Manitoba, (2005).

Modigliani, F. and Miller, M.H. 'The cost of capital, corporation finance and the theory of investment', American Economic Review 53 (1958), 261-97.

Myers, S.C. 'The capital structure puzzle', Journal of Finance 39 (1984), 575-92.

Myers, S.C. 'Determinants of corporate borrowings', Journal of Financial Economics 13 (1977), 187-221.

Myers, S.C and Majluf, N.S. 'Corporate financing and investment decisions when firms have information that investors do not have', Journal of Financial Economics 13 (1984), 187221.

Nishioka, S., and Baba, N. 'Dynamic capital structure of Japanese firms: How far has reduction of excess leverage progressed in Japan', Bank of Japan working paper series, 04-E-16, (2004).

Petersen, M.A., and Rajan, R.G. 'The benefits of lending relationship: Evidence from small business data', Journal of Finance 49(1) (1994), 3-37.

Rajan, R.G. and Zingales, L. 'What do we know about capital structure? Some evidence from international data', Journal of Finance 50(5) (1995), 1421-60.

Reeb, D., Kwok, C. and Baek, H. 'Systematic risk of the multinational corporation', Journal of International Business Studies 29(2) (1998), 263-279.

Shapiro, A.C. Multinational Financial Management, $5^{\text {th }}$ edition, (Prentice-Hall, New Jersey), (1996).

Singh, M. and Nejadmalayeri, A. 'Internationalization, capital structure, and cost of capital: Evidence from French corporations', Journal of Multinational Financial Management 14 (2004), 153-169.

Stulz, R. 'Managerial discretion and optimal financing policies', Journal of Financial Economics 26 (1990), 3-27.

Titman, S. and Wessels, R. 'The determinants of capital structure choice', Journal of Finance 43 (1988), 1-18.

Wald, J.K. 'How Firm Characteristics Affect Capital Structure: An International Comparison', Journal of Financial Research 22(2) (1999), 161-187.

White, H. 'A heteroskedasticity-consistent covariance matrix and a direct test for heteroskedasticity', Econometrica 48 (1980), 817-838.

Wright, F.W., Madura, J. and Wiant K.J. 'The differential effects of agency costs on multinational corporations', Applied Financial Economics 12(5) (2002), 347-59. 


\section{Table 1}

\section{Descriptive statistics of sample variables}

This table reports variable descriptive statistics of the sample variables for 360 Japanese multinational corporations (MNCs) and domestic corporations (DCs) over 10 years to 2003. Results of t-tests and Wilcoxon/Mann Whitney tests are reported in the final two columns respectively. Summary statistics are mean, median, maximum, minimum, standard deviation and number of observations for MNCs, DCs, and all firms in the sample. LEVERAGE is long-term debt scaled by long-term debt plus market value of equity. Firm age is the natural logarithm of the age of the firm in years from date of incorporation. Agency costs is estimated as the ratio of research and development expenses to sales. The proxy for bankruptcy risks is estimated as the lagged Altman Z-score. The proxy for business risk is estimated as the de-geared beta of ordinary equity. The proxy for collateral value of assets is estimated as the ratio of tangible assets to total assets. The proxy for free cash flow is estimated as earnings before interest and tax adjusted for depreciation, amortization, taxation, dividends and interest paid scaled by total assets. The proxy for foreign exchange risk is estimated as the ratio of foreign sales to total sales. The proxy for growth opportunities facing the firm is estimated as the average percentage change in total assets over the previous four years. The proxy for non-debt tax shields is estimated as total annual depreciation expense scaled by total assets. The proxy for political risk faced by the firm is estimated as a function of the proportion of revenue from different countries weighted by a political risk factor. The proxy for profitability is estimated as the average net income to total sales for the past four years. The proxy for firm size is estimated as the natural logarithm of total assets.

*** indicate significance at $1 \%$ level. 


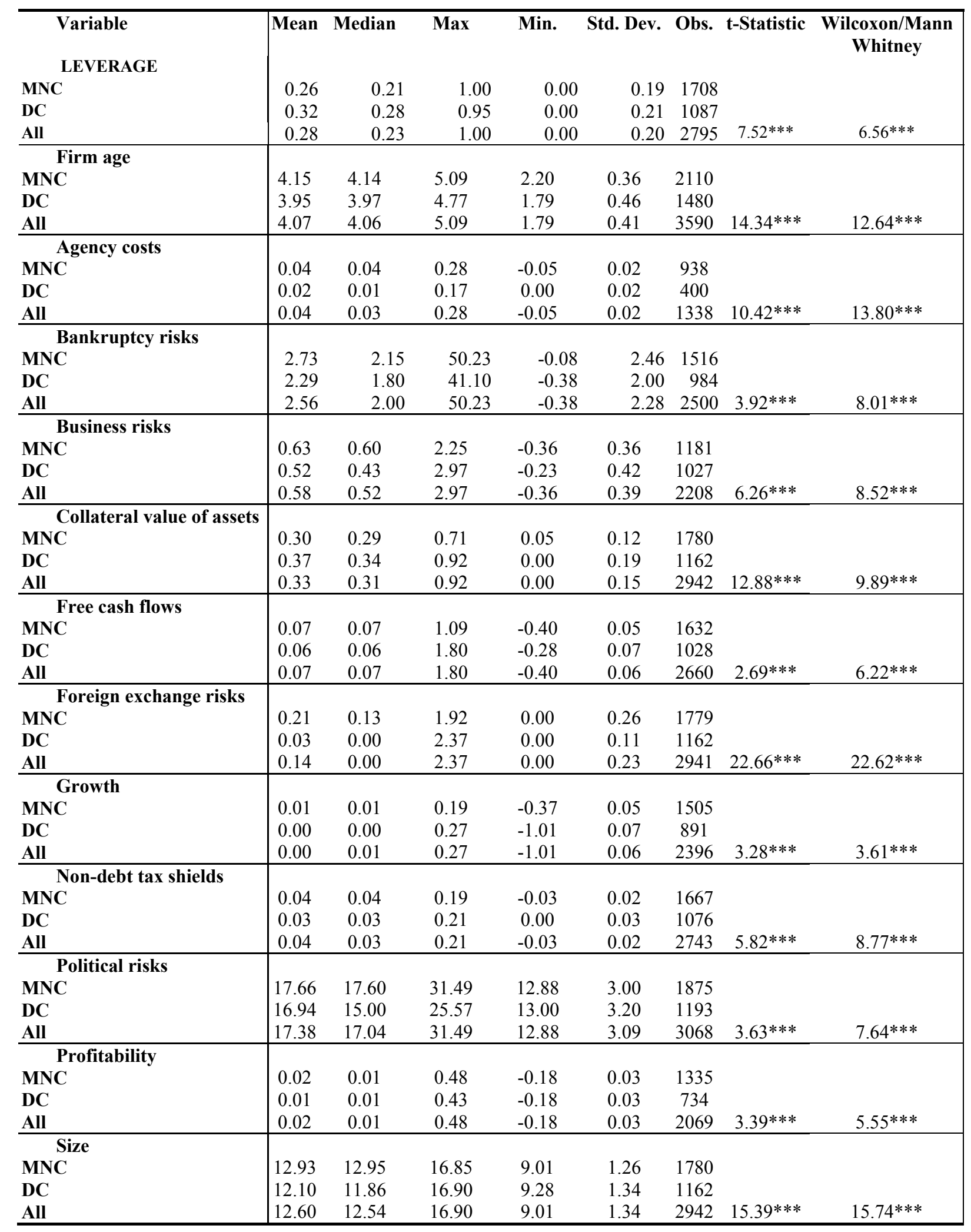


Table 2

Capital structure determinants

This table reports the results of the following pooled cross-sectional time series regression (Model 1) on the full sample of 360 Japanese multinational corporations (MNCs) and domestic corporations (DCs) over 10 years to 2003 as well as on the sample of domestic and multinational corporations separately:

$$
\begin{aligned}
\operatorname{LEVERAGE}_{i, t} & =\alpha_{i}+\beta_{1} A G E_{i, t}+\beta_{2} A G N C Y_{i, t}+\beta_{3} \text { BCPTY }_{i, t}+\beta_{4} \text { BUSRISK }_{i, t}+\beta_{5} \mathrm{CVA}_{i, t} \\
& +\beta_{6} \mathrm{FCF}_{i, t}+\beta_{7} F X_{i, t}+\beta_{8} G R O W_{i, t}+\beta_{9} \operatorname{NDTS}_{i, t}+\beta_{10} \text { POLR }_{i, t} \\
& +\beta_{11} \text { PROF }_{i, t}+\beta_{12} \operatorname{SIZE}_{i, t}+\varepsilon_{i, t}
\end{aligned}
$$

where $L E V E R A G E_{i, t}$ is the ratio of long-term debt to long-term debt plus market value of equity. $A G E_{i, t}$ is the natural logarithm of the age of the firm in years from date of incorporation. $A G N C Y_{i, t}$ is a proxy for agency costs and is estimated as the ratio of research and development expenses to sales. $B C P T Y_{i, t}$ is a proxy for bankruptcy risks and is estimated as the lagged Altman Z-score. BUSRISK $K_{i, t}$ is a proxy for business risk and is estimated as the de-geared beta of ordinary equity. $C V A_{i, t}$ is a proxy for collateral value of assets and is estimated as the ratio of tangible assets to total assets. $F C F_{i, t}$ is a proxy for free cash flow and is estimated as earnings before interest and tax adjusted for depreciation, amortisation, taxation, dividends and interest paid scaled by total assets. $F X_{i, t}$ is a proxy for foreign exchange risk and is estimated as the ratio of foreign sales to total sales. $G R O W_{i, t}$ is a proxy for growth opportunities facing the firm and is estimated as the average percentage change in total assets over the previous four years. $N D T S_{i, t}$ is a proxy for non-debt tax shields and is estimated as total annual depreciation expense scaled by total assets. $P O L R_{i, t}$ is a proxy for political risk faced by the firm and estimated as a function of the proportion of revenue from different countries weighted by a political risk factor. $P R O F_{i, t}$ is a proxy for profitability and is estimated as the average net income to total sales for the past four years. $S I Z E_{i, t}$ is a proxy for firm size and is estimated as the natural logarithm of total assets. MNCs represent multinational corporations and DCs represent domestic corporations.

\begin{tabular}{|c|c|c|c|c|c|c|}
\hline \multirow[t]{2}{*}{ Variable } & \multicolumn{2}{|c|}{ Full sample } & \multicolumn{2}{|c|}{ MNCs } & \multicolumn{2}{|r|}{ DCs } \\
\hline & Coefficient & t-Statistic & Coefficient & t-Statistic & Coefficient & th-Statistic \\
\hline Constant & -0.16 & $-1.67 *$ & -0.13 & -1.07 & -0.36 & $-2.27 * *$ \\
\hline Age & 0.04 & $2.74 * * *$ & 0.01 & 0.70 & 0.08 & $3.09 * * *$ \\
\hline Agency costs & -0.83 & $-4.29 * * *$ & -0.74 & $-3.61 * * *$ & -0.59 & $-1.99 * *$ \\
\hline Bankruptcy risks & -0.03 & $-3.32 * * *$ & -0.03 & $-3.68 * * *$ & -0.01 & -1.16 \\
\hline Business risks & -0.14 & $-8.05 * * *$ & -0.09 & $-4.51 * * *$ & -0.22 & $-6.47 * * *$ \\
\hline Collateral value of assets & 0.31 & $4.45 * * *$ & 0.37 & $3.66^{* * *}$ & 0.29 & $3.34 * * *$ \\
\hline Free cash flows & -0.47 & -1.63 & -0.23 & -0.99 & -0.89 & $-3.07 * * *$ \\
\hline Foreign exchange risks & -0.05 & $-2.28 * *$ & -0.01 & -0.44 & -0.09 & -1.09 \\
\hline Growth & -0.16 & -1.56 & -0.59 & $-3.66 * * *$ & -0.02 & -0.24 \\
\hline Non-debt tax shields & -0.50 & -0.98 & -1.78 & $-2.85 * * *$ & 0.76 & 1.34 \\
\hline Political risks & 0.00 & 0.66 & 0.00 & -0.88 & 0.01 & 1.48 \\
\hline Profitability & -0.56 & $-2.75 * * *$ & -0.67 & $-3.63 * * *$ & -0.64 & $-2.06 * *$ \\
\hline Size & 0.03 & $7.97 * * *$ & 0.04 & $6.89 * * *$ & 0.03 & $3.51 * * *$ \\
\hline Adjusted R-squared & 0.50 & & 0.51 & & 0.51 & \\
\hline F-statistic & $67.04 * * *$ & & $47.56 * * *$ & & $22.81 * * *$ & \\
\hline
\end{tabular}

Sample t-statistics are White (1980) adjusted for heteroskedasticity.

$* * *, * *$ and $*$ denotes significance at the $1 \%, 5 \%$ and $10 \%$ levels respectively. 
Table 3

Interaction effects in capital structure determinants for multinational corporations

This table reports the results of the following pooled cross-sectional time series regression (Model 2) on the sample of 360 Japanese multinational corporations (MNCs) and domestic corporations (DCs) over 10 years to 2003:

$$
\begin{aligned}
& \text { LEVERAGE } E_{i, t}=\alpha_{i}+\beta_{1} A G E_{i, t}+\beta_{2} A G N C Y_{i, t}+\beta_{3} B C P T Y_{i, t}+\beta_{4} B U S R I S K_{i, t}+\beta_{5} C V A_{i, t}+\beta_{6} F C F_{i, t} \\
& +\beta_{7} F_{i, t}+\beta_{8} \text { GROW }_{i, t}+\beta_{9} \text { NDTS }_{i, t}+\beta_{10} \text { POLR }_{i, t}+\beta_{11} \text { PROF }_{i, t}+\beta_{12} \operatorname{SIZE}_{i, t} \\
& +\beta_{13} M U L T_{i}+\beta_{14}\left(M U L T_{i} * A G E_{i, t}\right)+\beta_{15}\left(M U L T_{i} * A G N C Y_{i, t}\right)+\beta_{16}\left(M U L T_{i} * B C P T Y_{i, t}\right) \\
& +\beta_{17}\left(M_{U L T} * B U S R I S K\right)+\beta_{18}\left(M_{i} T_{i} * C V A_{i, t}\right)+\beta_{19}\left(M U L T_{i} * F C F_{i, t}\right) \\
& +\beta_{20}\left(M U L T_{i} * F X_{i, t}\right)+\beta_{21}\left(M U L T_{i} * G R O W_{i, t}\right)+\beta_{22}\left(M U L T_{i} * N D T S_{i, t}\right) \\
& +\beta_{23}\left(M_{U L T} * P O L R_{i, t}\right)+\beta_{24}\left(M U L T_{i} * P R O F_{i, t}\right)+\beta_{25}\left(M U L T_{i} * S I Z E_{i, t}\right)+\varepsilon_{i, t}
\end{aligned}
$$

where $L E V E R A G E_{i, t}$ is the ratio of long-term debt to long-term debt plus market value of equity. $A G E_{i, t}$ is the natural logarithm of the age of the firm in years from date of incorporation. $A G N C Y_{i, t}$ is a proxy for agency costs and is estimated as the ratio of research and development expenses to sales. $B C P T Y_{i, t}$ is a proxy for bankruptcy risks and is estimated as the lagged Altman Z-score. BUSRISK $K_{i, t}$ is a proxy for business risk and is estimated as the de-geared beta of ordinary equity. $C V A_{i, t}$ is a proxy for collateral value of assets and is estimated as the ratio of tangible assets to total assets. $F C F_{i, t}$ is a proxy for free cash flow and is estimated as earnings before interest and tax adjusted for depreciation, amortisation, taxation, dividends and interest paid scaled by total assets. $F X_{i, t}$ is a proxy for foreign exchange risk and is estimated as the ratio of foreign sales to total sales. GROW percentage change in total assets over the previous four years. $N D T S_{i, t}$ is a proxy for non-debt tax shields and is estimated as total annual depreciation expense scaled by total assets. $P O L R_{i, t}$ is a proxy for political risk faced by the firm and estimated as a function of the proportion of revenue from different countries weighted by a political risk factor. $P R O F_{i, t}$ is a proxy for profitability and is estimated as the average net income to total sales for the past four years. $S I Z E_{i, t}$ is a proxy for firm size and is estimated as the natural logarithm of total assets. $M U L T_{i}$ is a dichotomous variable for multinationality and equals unity if the firm is a multinational and zero otherwise.

Sample t-statistics are White (1980) adjusted for heteroskedasticity.

$* * *, * *$ and $*$ denotes significance at the $1 \%, 5 \%$ and $10 \%$ levels respectively.

\begin{tabular}{lrl}
\hline Variable & Coefficient & t-statistics \\
\hline Constant & -0.36 & $-2.29 * *$ \\
Age & 0.08 & $3.12 * * *$ \\
Agency costs & -0.59 & $-2.01 * *$ \\
Bankruptcy risks & -0.01 & -1.17 \\
Business risks & -0.22 & $-6.52 * * *$ \\
Collateral value of assets & 0.29 & $3.37 * * *$ \\
Free cash flows & -0.89 & $-3.09 * * *$ \\
Foreign exchange risks & -0.09 & -1.10 \\
Growth & -0.02 & -0.25 \\
Non-debt tax shields & 0.76 & 1.35 \\
Political risks & 0.01 & 1.49 \\
Profitability & -0.64 & $-2.08 * *$ \\
Size & 0.03 & $3.54 * * *$ \\
Multinationality & 0.24 & 1.20 \\
Multinationality *Age & $\mathbf{- 0 . 0 6}$ & $\mathbf{- 1 . 8 8 *}$ \\
Multinationality *Agency & -0.14 & -0.40 \\
Multinationality *Bankruptcy risks & -0.02 & -1.63 \\
Multinationality *Business risks & $\mathbf{0 . 1 4}$ & $\mathbf{3 . 4 5 * * *}$ \\
Multinationality *Collateral value of assets & 0.07 & 0.54 \\
Multinationality *Free cash flow & $\mathbf{0 . 6 6}$ & $\mathbf{1 . 7 7 *}$ \\
Multinationality *Foreign exchange risk & 0.08 & 0.93 \\
Multinationality *Growth & $\mathbf{- 0 . 5 8}$ & $\mathbf{- 3 . 3 0 * * *}$ \\
Multinationality *Non-debt tax shields & $\mathbf{- 2 . 5 4}$ & $\mathbf{- 3 . 0 2 * * *}$ \\
Multinationality *Political risks & $\mathbf{- 0 . 0 1}$ & $\mathbf{- 1 . 7 3 *}$ \\
Multinationality *Profitability & -0.03 & -0.09 \\
Multinationality * Size & 0.01 & 0.76 \\
Adjusted R-squared & & \\
F-statistic & & \\
\hline
\end{tabular}

